\title{
Concern regarding the "Debt" created by Rule 14.10.9 of the Government Employees' Pension Fund Rules
}

MC Marumoagae*

\section{P.E.R}

Author

Motseotsile Clement Marumoagae

Affiliation

University of the Witwatersrand South Africa

Email

Clement.Marumoagae@wits.ac.za

Date published 21 April 2016

Editor Prof C Rautenbach

How to cite this article

Marumoagae MC "Concern regarding the "Debt" created by Rule 14.10.9 of the Government Employees' Pension Fund Rules PER / PELJ 2016(19) - DOI

http://dx.doi.org/10.17159/1727-

3781/2016/v19i0a741

\section{Copyright}

\section{cc) (i)}

This work is licensed under a Creative Commons Attribution 4.0 International License.

\section{DOI}

http://dx.doi.org/10.17159/1727-

3781/2016/v19i0a741

\begin{abstract}
This paper highlights the prejudicial effect of the rule within the rules of the Government Employees Pension Fund (GEPF), which allows this fund to create a "divorce debt" for its member when the court has ordered that part of such a member's pension interest be paid over to his or her spouse. I argue that this debt is in fact a loan which is provided to the member, which he or she would be expected to pay when he or she exits the fund, with interest. This is despite the fact that the rules of the GEPF do not permit the granting of loans to its members. I argue that the creation of such a loan has the effect of diminishing the GEPF's member's benefits, and thus threaten his or her social security, and can lead to the member becoming unable to provide for himself or herself when he or she reaches retirement age.
\end{abstract}

\section{Keywords:}

Government Employees Pension Fund; Divorce Debt; Pension Interest; Social Security. 


\section{Introduction}

Given South Africa's low savings rate and present twin fiscal and current account deficits, pension funds play a vital role in ensuring that people in formal employment are able to save for their retirement. Pension funds also play an important role in the economic development of the country. ${ }^{1}$ As such, the manner in which pension funds are managed has far reaching consequences for the financial stability of the country. The manner in which pension funds are managed can also have an impact on members of pension funds' ability to provide for themselves when they exit such pension funds due to retirement, resignation, dismissal, retrenchments and most recently, divorce

The South African retirement industry is divided into two systems. On the one hand, there is a private sector which is governed by the Pension Funds Act $^{2}$ and consists of small to medium pension funds. On the other hand, there are several public pension funds governed and regulated by their own legislation. ${ }^{3}$ All pension funds, irrespective of whether they fall within the public or private sector, differ in terms of the number of their members and the extent of the assets they manage. The Government Employees Pension Fund (hereinafter referred to as the "GEPF") is the largest pension fund scheme not only in South Africa but in Africa as a whole in terms of both membership and assets. The GEPF has more than 1.2 million active members, all of whom are government employees. ${ }^{4}$

* Motseotsile Clement Marumoagae. LLB LLM (Wits) LLM (NWU) Diploma in Insolvency Law Practice (UP). Senior Lecturer, University of the Witwatersrand. E-mail: Clement.Marumoagae@wits.ac.za.

1 National Treasury 2012 http://www.treasury.gov.za/comm_media/press/2012/Incentivising\%20non-retirement\%20savings.pdf.

2 Act 24 of 1956 (hereinafter referred to as PFA). See Mhango 2014 Speculum Juris 102 , who correctly submits that the Pension Funds Act is the primary legislation that regulates private pension fund organizations.

3 For instance, the Communications Pension Fund (Telkom Pension Find) and Post Office Pension Fund are regulated by Post Office Act 44 of 1958, the Transnet Pension Fund is regulated by the Transnet Pension Fund Act 62 of 1990, as amended, and the Government Employees Pension Fund (hereinafter referred to as GEPF) is regulated by Government Employees Pension Law of 1996, as amended. Also see generally Marumoagae 2013 De Rebus 38-41, Ngewu v Post Office Retirement Fund 20134 BCLR 421 (CC) and Wiese $v$ Government Employees Pension Fund 20126 BCLR 599 (CC).

4 See GEPF date unknown http://www.gepf.gov.za/index.php/about_us/article/who-isgepf, where it is also stated that the GEPF is a defined benefit pension fund that was established in May 1996 when various public sector funds were consolidated. Its core business is to manage and administer pensions and other benefits for government 
Pension funds are managed by boards of trustees, who are in turn guided by pension funds' rules on how to manage and administer their funds. The GEPF is the only pension fund in South Africa which is empowered by its rules to pay over claims which non-member spouses have in terms of the provisions of the Divorce $A c t^{5}$ against its members when the parties divorce, using methods which are not compliant with section 7 (8) of the Divorce Act. Rule 14.10.9 of the rules of the GEPF read together with rule $24 \mathrm{~A}(2)$ (d), which was introduced by recent amendments to the GEPF law, allows the fund to make payment to the non-member spouse and to create what is referred to as a "divorce debt", which the divorcing member is expected to pay back to the fund with interest when he or she exits the fund. It is unfortunate that the difficulties arising from the creation of the "divorce debt" by the rules of the GEPF have not yet received academic and judicial attention in South Africa. Not much has been written on this issue yet.

The purpose of this paper is to highlight the prejudice which is created by the rules of the GEPF against its divorcing members. I will consider the constitutionality of these rules in the light of the GEPF members' right to social security and the right to be treated the same as members of other pension funds when they divorce. In this paper I argue that the GEPF's rules unjustifiably treat divorcing members of the GEPF as the fund's indirect investment option by granting loans to them which they are forced to pay back with interest in circumstances which are not advocated by section 7 (8) of the Divorce Act. This is a challenge which divorced members of the GEPF are experiencing when exiting the fund, at which point they are required to pay back such "divorce debts" arising from amounts which were paid on their behalf when their former spouses claimed their share of the pension interests in accordance with sections 7 (7) and (8) of the Divorce Act.

This paper addresses a practical problem which seldom reaches superior courts for determination, which I have encountered in practice. It is unfortunate that most of these matters end up in regional magistrates' courts and are thus not reported, which might explain the lack of academic coverage as far as they are concerned. I hope that this article will encourage divorce lawyers to advise their clients to challenge this rule in the High Court when the opportunity presents itself. The discussion relating to the sharing of the pension interest when parties divorce and some of the challenges

employees in South Africa and it currently has in excess of 300000 pensioners and beneficiaries, and assets worth more than $\mathrm{R} 1$ trillion.

5 70 of 1979. 
arising thereto are beyond the scope of this paper and have been discussed elsewhere. ${ }^{6}$

\section{Divorce debt created by the GEPF rules}

\subsection{Clean break principle}

The GEPF is administered by the Government Pensions Administration Agency on behalf of National Treasury and reports directly to the Minister of Finance. The fund is a direct initiative of the government to ensure that public servants when they retire are able to support themselves without relying on the state. The GEPF is regulated by Proclamation 21 of 1996, which is the Government Employees Pension Law. This law contains the rules of the GEPF. There seems not to be a difference between the Government Employees Pension Law and the rules of the fund. In actual fact, the rules and law are contained in the same document, titled "Government Employees Pension Rule and Law" and obtainable from the GEPF website. ${ }^{7}$ In 2011 the Government Employees Pension Law, 1996 was amended by the Government Employees Pension Law Amendment Act. $^{8}$ This amendment Act sought to align the GEPF with private pension funds by introducing the so-called clean break principle, which allows the fund to pay over the portion of its divorced member's pension interest to that member's ex-spouse when directed to do so by a decree of divorce. ${ }^{9}$

A detailed discussion relating to the clean break principle is beyond the scope of this paper. However, it suffices to mention that the GEPF board of trustees took a unique decision to establish a procedure within the GEPF rules which allows the fund to comply with the clean break principle by effecting payment to the non-member spouse to satisfy the divorce order,

6 See Marumoagae 2014 Speculum Juris 54-73 and Marumoagae 2014 PER 24882524.

GEPF 2014 http://www.gepf.gov.za/index.php/about_us/article/pension-fund-rules. 19 of 2011.

Nevondwe 2014 "Divorce orders: issues for pension funds" 8, who argues that "[t]he clean-break principle was introduced in the private sector pension funds on 1 November 2008 by the introduction of the Pension Funds Amendment Act 11 of 2007 and Financial Services Laws General Amendment Act. These two pieces of legislation amended section 7(8)(a) (i) of the Divorce Act which provides that a non-member spouse of a member of a retirement fund on divorce could be awarded by a court a portion of benefits that the member would have received had he or she resigned on the date of divorce. However, in terms of the Divorce Act read with the Pension Funds $A c t$, the non-member spouse was only entitled to receive that share when the member became entitled to a benefit in terms of the Rules of the fund, that is, on his or her latter retirement or termination of membership which could been many years after the date of divorce. Post amendments provide that a benefit is deemed to accrue to the principal member on the date a decree of divorce is granted by a court". 
but in the process unjustifiably creating a "debt" for its divorcing members. Rule 14.10 of the GEPF rules purports to deal with the assignment of a share of a member's pension interest to his or her former spouse. However, the fund does not assign a portion of its divorcing member's pension interest to the non-member spouse. Instead, the fund pays such an amount from its reserves without interfering with the member's pensionable service generally or the pension benefits specifically of its divorcing member. Rule 14.10.1 to rule 14.10 .5 of the GEPF rules deal with the election by the nonmember spouse and the manner of payment of his or her portion in accordance with the divorce order.

\subsection{Non Compliance with Section 7(8) of the Divorce Act}

None of the provisions of rule 14.10 of the GEPF rules are clear as to where exactly the fund would obtain the money which it pays over to the nonmember spouse to satisfy the divorce order. It is clear however, that such an amount is not taken from the divorcing member's pension interest as directed in the divorce decree in accordance with section 7 (8) of the Divorce Act. This can be deduced from rule 14.10.6.1 of the GEPF rules, which empowers the fund after having made payment to the non-member spouse to record in the books of the fund a "divorce debt" in respect of the member in the amount of the former spouse's share. It is submitted that the idea behind the creation of the "divorce debt" came after the realisation that the clean break principle interferes with both the pensionable service and the pension credit of divorcing members. A system which would allow the fund to comply with the clean break principle and at the same time not to interfere with its divorcing members' pension benefits had to be put in place. The board realised that

[w] hen the benefit is paid to the non-member spouse on divorce ... the member's benefit would be reduced. GEPF could either reduce the members' pensionable service or create a 'debt' which would be deducted against their benefit when they finally exited the Fund..$^{10}$

It is worth noting that the fact that the divorce would lead to the reduction of the pensionable interest of a member of a pension fund, when a portion of the pension interest has been claimed in accordance with the divorce decree, is a direct financial consequence of marriages in community of property. This is because the member's pension interest is deemed to be part of his or her estate, which entitles his or her spouse to be able to claim

10 GEPF 2014 http://www.gepf.gov.za/index.php/news/article/gepf-invests-r312-millionin-a-solar-park-project. In this document the manner in which the GEPF understands the Clean Break Principle is unconvincingly explained. 
a portion thereof during divorce. ${ }^{11}$ This is applicable to all pension funds in South Africa, upon the divorce of their members who are married either in community of property or out of community of property with the application of the accrual system. Indeed, divorce would affect the pension benefits of members of pension funds. However, the board of trustees of the GEPF chose to treat the GEPF and its divorcing members differently from the members of other funds, and thus created a system which would circumvent the impact of the clean break principle on its members by opting to create a "debt" which would be deducted against their divorcing members' benefits when they exit the Fund. The creation of a "debt" resembles the granting of a loan by the fund to its divorcing members

Even the South African Law Commission (as it was referred to then) did not envisage the fund's making loans to its members for the purpose of settling a claim in terms of the divorce order, and paying the non-member spouse from any source other than the member's portion of his pension benefits. At the time when the clean break principle was not yet in force, the commission stated that it:

accepted the principle that the right which a member of a pension fund has to receive a pension in accordance with the rules of the fund at a future date or event specified by such rules, forms an important part of such member's assets even before the pension becomes payable although the pension is not realisable before the specified date or event. The said right was described as the member's "pension interest". It was further accepted that in the event of the divorce of such member his or her divorced spouse (referred to as the non-member spouse) ought to be able to share in the member's pension interest in accordance with the matrimonial property dispensation which is applicable to the marriage. It was therefore recommended that the pension interest of a member of a pension fund should, for purposes of the division of the assets of the spouses on divorce, be deemed to be part. ${ }^{12}$

It is crucial to note that now, as the law stands, the date of accrual of the benefit has been accelerated to the date of divorce. The non-member spouse does not have to wait until the member exits the fund at a future date, which may be long after the divorce, in order to be able to claim and receive his or her share of the member's pension interest. ${ }^{13}$ This shows that the non-member spouse's claim lies against the member's pension interest

11 See section 7 (7) of the Divorce Act.

12 SALC Discussion paper 1998 http://www.justice.gov.za/salrc/dpapers/dp77_prj112_ 1998.pdf.

13 See Cockcroft v Mine Employees' Pension Fund 20073 BPLR 296 (PFA), Mouton v Southern Staff Pension Fund 20034 BPLR 4581 (PFA), wherein this position was found to be unsatisfactory in that it undermined the clean break principle. Also see Nevondwe 2012 Insurance and Tax 32-35 and Ngewu v Post Office Retirement Fund 20134 BCLR 421 (CC) and Wiese $v$ Government Employees Pension Fund 20126 BCLR 599 (CC). 
held in that member's pension credit, and not against the fund itself. The non-member spouse is entitled to only a percentage awarded in terms of the divorce decree relating to what the member has been able to accumulate in his or her pension benefits. It is difficult to understand the wisdom of the GEPF's actually lending its divorcing members money to settle the non-member spouses' claims, while its members already have resources in the form of their pension interests, which would enable them to satisfy such claims. It is submitted that the "debt" system created by the GEPF is against the spirit of section 7 (8) of the Divorce Act ${ }^{14}$, which provides that:

Notwithstanding the provisions of any other law or the rules of any pension fund- the court granting a decree of divorce in respect of a member of such a fund, may make an order that-

(a) Any part of the pension interest of that member which, by virtue of subsection (7), is due or assigned to the other party to the divorce action concerned, shall be paid by that fund to that:

(i) other party when any pension benefits accrue in respect of that member; ....:

This section clearly empowers the court to directly order the pension fund scheme, irrespective of what is contained in its rules, to pay the percentage indicated in the divorce decree of its member's pension interest to the nonmember spouse. It can be argued that this section does not necessarily restrict or prohibit pension funds from settling the non-member spouse's claim by taking amounts from any source other than such a member's pension benefits. However, it is argued that this was not the intention of the legislature. Pension funds should simply comply with the decree of divorce and deduct part of their member's pension interest and award it to the nonmember spouse. Such a claim should be satisfied directly by the member's pension interest and not from any other source, because the decree of divorce would be explicit in that regard. Furthermore, section 7 (8) clearly

14 See Marumoagae 2013 De Rebus 38, who reflected that this section was brought as a result to the 1989 amendments which were made to the Divorce Act "through the Divorce Amendment Act 7 of 1989. These amendments allowed some relief to a spouse from whom the member was divorced who might otherwise receive nothing from the marriage. Prior to the amendment of the Divorce Act by the Divorce Amendment Act 7 of 1989, a pension interest which had not yet accrued, such as an interest in a pension fund, was not regarded as an asset in the estate of a spouse. After the amendment, which came into force on 1 August 1989, section 7(7)(a) was introduced to the Divorce Act and deemed a pension interest to be an asset in a spouse's estate for purposes of determining patrimonial benefits. The pension interest is defined in section 1 of the Divorce Act to mean the benefits to which the member of the fund would have been entitled in terms of the rules of the fund if his or her membership had been terminated on the date of the divorce on account of his or her resignation from office". 
provides the non-member spouse with an entitlement to lay a claim directly to the member's pension interest and not against the fund itself. There is therefore no need for the fund to satisfy the claim out of its own coffers. The divorcing member's pension benefits should be reduced by the fund to satisfy the non-member's spouse's claim. It is totally unnecessary for the fund to intervene with a view to "protecting" the member spouse's pension benefits from such a claim by itself undertaking to pay the claim on behalf of its member. This section specifically states that "any part of the pension interest of that member" shall be paid to the non-member spouse.

It is worrying that the rules of the GEPF do not make provision for consultation with the divorcing member of the fund to make an election as to whether the fund should satisfy the divorce claim on his or her behalf or simply comply with section 7 (8) of the Divorce Act by paying out the claim as directed in the divorce decree. This would provide the member with an opportunity to decide for himself or herself whether the fund should "protect" his or her pension benefits as well as his or her pensionable service by satisfying his or her former spouse's divorce claim on his or her behalf and thus create a "debt" against his or her name which he or she would be obliged to pay back when he or she exits the fund. It is unfortunate that this is done automatically without any consultation. Hence, in my view it is prejudicial to the divorcing members of the GEPF. Furthermore, even if there was provision for such consultation, the GEPF would still need to do more to educate its members regarding the option available to them when they are divorcing, as well as the advantages and disadvantages of the choices to be made, so that divorcing members can be in a position to make informed decisions.

It is worth noting that section 7 (8) of the Divorce Act effectively adds divorce as one of the grounds which may trigger the release of the member's pension interest and the division thereof, together with resignation, retirement, dismissal and retrenchment. Now, if the GEPF when its members divorce does not pay off the non-member spouses' claims directly from its members' pension interests, it effectively eliminates divorce as one of the trigger events which would lead to the release of its members' pension benefits. This means that the GEPF insists on making sure that its members could cash in their benefits from the fund only through resignation, retrenchment, dismissal or retirement. The fund would interfere with its members' pension benefits only when these events occur and not when members divorce. In order to achieve this and not to be seen as avoiding the application of the clean break principle, the board of trustees decided that the non-member spouse would be paid by the fund itself on behalf of 
its member in order not to interfere with the pension credit of the member, thus forcing the member when he or she exits the fund to pay back the amount which was paid by the fund to his or her former spouse. This means that the member's pension benefits and service are not adjusted in accordance with the divorce decree, and continues as if there was no divorce at all, which is contrary to what is expected from the fund by section 7 (8) of the Divorce Act.

By making provision in its rules to create such a "divorce debt", the GEPF effectively operates a business of indirectly granting loans to its members. It is well known in the private retirement industry that section 19 (5) of the Pension Funds Act allows funds regulated under this Act to grant housing loans to its members, but there is no such provision in the rules of the GEPF. The idea of the "divorce debt" created by the rules of the GEPF is surprising because it is well known that the GEPF does not lend money to any member or pensioner, simply because its rules do not make provision for loans. Hence, this "debt" is called a "divorce debt" instead of a loan. However, the manner in which it is granted resembles that in which a loan is made.

\subsection{Lack of Consent and Obligation to pay Interest}

Rule 14.10.9 of the rules of the GEPF provides that when a benefit becomes payable to the member in terms of these rules-

14.10.9.1 the amount of the gratuity, if any, then payable to the member must be reduced by the amount of the divorce debt; and

14.10.9.2 if the amount of the divorce debt exceeds the amount of the gratuity and there is an annuity payable to the member then-

(a) the capital value of the annuity must be determined by the actuary;

(b) the value determined by the actuary must be reduced by an amount equal to the balance of the divorce debt then remaining; and

(c) the capital value that results from this calculation must be annuitised by the actuary on a basis determined by the board in consultation with the actuary to determine the amount of the annuity which will then be payable. ${ }^{15}$

15 This rule must be read in conjunction with rule 24A (2)(d), which was introduced by the Government Employees Pension Fund Law Amendment Act 19 of 2011, which provides that: The amount of any pension benefit that is subsequently payable to the member in terms of the rules will be reduced by the equivalent of the amount of the share of the pension interest of the member which-(i) was deemed to accrue to the member as a benefit in advance of the benefit ordinarily payable in terms of the rules; and (ii) was assigned to the member's former spouse, less the amount of any additional voluntary contributions, if any, paid by the member to the Fund from time to time, and accumulated over the period from the date on which payment to the former spouse or transfer to the approved fund as referred to in paragraph (e) took place to 
At the time when the non-member spouse makes a claim to the member's pension interest in accordance with the divorce order, while not settling the claim from the member's pension benefits, the GEPF would nonetheless pay a certain or an ascertainable amount in terms of the percentage which the fund is ordered to pay by the court. It is then surprising that at the time when the member exits the fund such a member is required to pay back the "divorce debt" which is essentially the amount which was paid to the member's former spouse plus interest, as if such a member agreed to take up a loan with the fund. This is clear from the unconvincing explanatory article published on the GEPF's website, which among other things unequivocally and categorically states that:

\begin{abstract}
The new rules state that on the date of payment of a divorce benefit GEPF will create a debt against the member that is equal to the amount payable to the non-member spouse. The debt amount will build up, with interest, up until the member exits the Fund (and it will be reduced to the extent that the debt is partially repaid over the member's remaining period of service in the Fund). At the date of the member spouse's exit from the Fund the total value of the benefit will be determined, and will then be decreased by the outstanding amount of debt owed. ${ }^{16}$
\end{abstract}

This clearly illustrates that the GEPF is in the business of granting its members interest bearing loans, despite its rules making no provision for such. Assuming that the amount provided is not a loan, it is difficult to understand why such an amount would attract interest from the date it was paid to the non-member spouse to the date which the member is exiting the fund. It is more disturbing that in terms of rule 14.10.9.2 of the GEPF rules, it is possible for the "divorce debt" to be more than the gratuity or rather the value of the pension benefits due to the member when he or she exits the fund. If this happens then the fund's actuary has to determine the actual amount which will then be ultimately payable to the member. This simply means that without the intervention of the court the fund treats itself as a "secured creditor" of its divorced member, proves its own claim against its member on his or her pension benefits, executes its own claim against him or her, and ultimately ensures that it is paid because it holds the pension benefits on behalf of its member. Even if the member does not agree with the fund's methods, there would not be much that he or she could do except to review the fund's decision through a court of law, which process might be financially unsustainable for the member concerned. It is equally not helpful

the date on which the member first became entitled to a part or the whole of the balance of the benefit, with interest as the Board from time to time deems appropriate. 16 GEPF 2014 http://www.gepf.co.za/index.php/news/article/gepf-rule-changes. 
that the fund determines how much the member owes it through complex actuarial calculation which members may not be able to understand, and then decides how much is due to the member after satisfying its claim. Clearly this is unacceptable, and it is possible that the majority of the members of the GEPF, while aware of this system, may nonetheless not challenge this system, which ultimately prejudices them by substantially unnecessarily reducing their benefits.

Even though the member did not consent to the creation of the "divorce debt", such a debt attracts interest. ${ }^{17}$ Member spouses are obliged to settle this debt together with its accumulated interest. Further, given the fact that the rules of the GEPF provide for the creation of this "debt", this simply means that the debt is created by the operation of the rules themselves without any consultation with divorcing members, particularly if it is taken that such members must have read and understood the rules. It is submitted that the GEPF through its debt system, is acting as a credit provider. While the discussion regarding the impact (if any) of the National Credit Act ${ }^{18}$ is beyond the scope of this paper, it suffices to mention that it is important that credit providers when granting credit must comply with this Act. They must explain all the costs of granting a loan to the consumer, failing which they might be opening themselves to reckless lending. ${ }^{19} \mathrm{It}$ is submitted that if the GEPF creates a "divorce debt" which at the time when its member exits the fund would substantially reduce his or her pension benefits after the fund has paid itself, that would amount to reckless lending, because it would affect the member's ability to care for him/herself after his or her exit from the fund, which would be especially bad if the member had reached retirement age. It is submitted further that if indeed the "divorce debt" is a loan, then the rules of the GEPF must make express provision for this, and there must be a credit agreement between the fund and its divorcing member, which outlines the terms thereto. This would ensure that the divorcing member was adequately informed of how much was paid to his or her former spouse and how much he or she is expected to pay back to the fund when he or she exits the fund, as well as how the interest which is

See Rule 14.10 .9 of the rules of the GEPF read together with rule $24 \mathrm{~A}(2)(\mathrm{d})$.

34 of 2005.

19 Section 81 of the National Credit Act 34 of 2005. Also see Standard Bank of South African Ltd $v$ Kelly (unreported) case number 23427/2010 of 25 January 2011 and Bell 2006 Business Law \& Tax Review 9, who argues that "[a] credit agreement is reckless if at the time it was concluded, a credit provider failed to conduct an assessment or despite having conducted a proper assessment concluded the agreement when the available information indicated that the consumer did not generally understand the proposed agreement or that the transaction would render the consumer overindebted". 
attracted by that debt would be calculated. However, should the rules of the GEPF make provision for the fund to grant loans to its members for the purposes of settling divorce debts, that would be contrary to the spirit of section 7 (8) of the Divorce Act, as argued above.

\section{Infringement of the right to social security and to be treated equally and fairly}

\subsection{The right to social security}

It cannot be disputed that the money which employees save and invest in their pension schemes forms the cornerstone of their retirement financial security. Such savings and investments are made on the basis of the fact that upon retirement, such employees would not be a financial burden to the state and they will continue to comfortably support themselves. Indeed, when a person retires from active employment, he or she still wishes to maintain more or less the same standard of living that he or she enjoyed during his or her working life. A person who is employed would need some form of income during old age for his or her own support and that of his or her family. Pension benefits are intended for the protection of members of retirement funds and their dependants and should therefore not be eroded unnecessarily. ${ }^{20}$ It is unfortunate, however, that the rules of the GEPF allow the fund to unnecessarily erode the pension benefits of its divorcing members by creating a system which can potentially reduce their benefits when they exit the fund. The creation of a "divorce debt", which makes divorcing members of the fund indebted to the fund by amounts which are not necessarily determinable at the time the debt is created, and which are going to be determined ony at the time when divorcing members exit the fund, after actuarial calculations have been made by the fund's actuaries, threatens the members' right to social security as envisaged in section 27 of the Constitution of the Republic of South Africa, 1996. Section 27(1)(c) provides that everyone has a right to have access to social security. ${ }^{21}$ One idea behind social security initiatives in the form of pension funds is, among others, to guarantee an adequate living standard and also to safeguard the standard of living of employees when they are no longer working in order to ensure that they do not depend on the state..$^{22}$

The threat is based on the fact that such a debt attracts interest, a percentage of which is not disclosed on the rules of the fund, which means

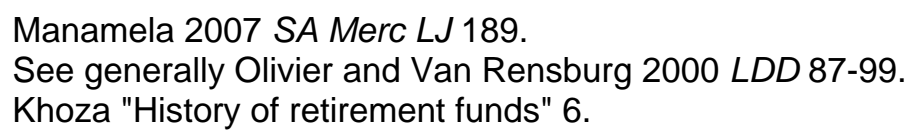


that the amount which divorcing members are obliged to pay back to the fund can be more than half if not more than the amount which such members would be eligible to receive from the fund. This might indeed be the case if the non-member spouse was awarded $50 \%$ or more of the member's pension interest through the divorce decree, which is normally the case in divorce disputes. If the fund did not interfere with the member's pension benefits, in that the fund paid the amount from within its reserves, then the member would be indebted to the fund in the amount equal to the amount paid by the fund to his or her former spouse, but most importantly, plus an undisclosed amount of interest. Depending on the number of years which the member would still be active within the fund, such interest may be substantial. If so, this would drastically reduce his or her benefits when he or she exits the fund, and would ultimately affect his or her ability to live a comfortable life when he or she retires. It is doubtful whether the "divorce debt" system created by the rules of the GEPF is reasonable, as it could potentially impoverish its divorcing members and compel them to rely on the state upon their retirement. It is submitted that divorcing members of the GEPF could successfully challenge the GEPF's debt system on the basis that it unjustifiably infringes upon their right to social security, and iss therefore unconstitutional.

\subsection{The right to equality}

The fact that the GEPF is the only fund which implements a debt system for its divorcing members might also make the fund vulnerable to a constitutional challenge under the equality clause of the Bill of Rights. This is because divorcing member spouses of the GEPF are treated differently from divorcing members of other pension funds governed by either the PFA or other laws, who are not burdened by indirect loans from their pension funds. It is submitted that this differential treatment violates section 9(1) of the Constitution of the Republic of South Africa, 1996. In order to assess whether or not the debt system unfairly discriminates against members of the GEPF, the courts would employ the unfair discrimination test crafted by the Constitutional Court in Harksen $v$ Lane. ${ }^{23}$ It is questionable whether the

23 In 199711 BCLR 1489 (CC) para 54, the Court laid down the test as follows: (a) Does the provision differentiate between people or categories of people? If so, does the differentiation bear a rational connection to a legitimate government purpose? If it does not then there is a violation of section 8(1). Even if it does bear a rational connection, it might nevertheless amount to discrimination; (b) Does the differentiation amount to unfair discrimination? This requires a two stage analysis: (b)(i) Firstly, does the differentiation amount to "discrimination"? If it is on a specified ground, then discrimination will have been established. If it is not on a specified ground, then whether or not there is discrimination will depend upon whether, objectively, the 
debt system bears a rational connection to a legitimate governmental purpose. ${ }^{24}$ The GEPF might argue that by creating a debt system it has sought to protect its divorcing members' pension benefits so that they cannot be affected by the divorce, which has the effect of reducing the pensionable service of its members, when the pension interest has to be divided. While the fund might be protecting the member at the time of the divorce, however, the fund itself creates the same threat (if not a more extensive threat) to the detriment of the member when the member exits the fund by reducing the member's benefits by the amount of the debt plus the interest it charges. Perhaps if there was no interest payable on that amount, such an argument might hold water. It is submitted that by making provision for the debt system, the GEPF has fallen foul of the constitutional standard of equality, because this system does not have a legitimate purpose or a rational relationship to the purpose advanced to validate it. ${ }^{25}$ It is further submitted that the GEPF does not seem to be offering any convincing explanation, let alone a rational basis, for creating a debt system, while other pension funds are not making such a provision.

It is hoped that this article will spark a debate not only between divorce attorneys and pension law scholars but also administrators within the GEPF and relevant government officials who would hopefully provide a contextual understand of why this system was created.

\section{Conclusion}

It has been shown in this paper that the GEPF is the only fund which on the date of the payment of a divorce claim to its member's former spouse creates a "divorce debt" against its member that is equal to the amount payable to the former spouse. I have argued that there is no rational justification for the creation of such a debt, and that this system amounts to the GEPF's merely granting its divorcing members loans and thus treating

ground is based on attributes and characteristics which have the potential to impair the fundamental human dignity of persons as human beings or to affect them adversely in a comparably serious manner; (b)(ii) If the differentiation amounts to "discrimination", does it amount to "unfair discrimination"? If it has been found to have been on a specified ground, then unfairness will be presumed. If on an unspecified ground, unfairness will have to be established by the complainant. The test of unfairness focuses primarily on the impact of the discrimination on the complainant and others in his or her situation. If, at the end of this stage of the enquiry, the differentiation is found not to be unfair, then there will be no violation of section 8(2); (c) If the discrimination is found to be unfair then a determination will have to be made as to whether the provision can be justified under the limitations clause.

$24 \quad$ Van der Merwe $v$ Road Accident Fund 20064 SA 230 (CC) para 48.

25 Prinsloo v Van der Linde 1997 3 SA 1012 (CC) para 25. 
them as its indirect investment option. This is because such a debt builds up with interest until the member exits the fund. On the date when the divorcing member would be exiting the fund, the total value of the pension benefits would be determined through actuarial calculations, and such benefits would be effectively reduced by the amount of the debt determined by the fund's actuaries.

It is possible for the divorced member to reduce the debt by periodic payments during his or her period of service in the fund, but this does not make the system reasonable. I have argued that the system is unreasonable to the extent that it can be challenged on constitutional grounds, in that first it infringes upon the divorced members' rights to social security to the extent that it could potentially reduce their pension benefits, leading them to depend on the state post their retirement. Secondly, I have argued that the system is discriminatory to the extent that it is applicable to members of the GEPF only and not to members of other pension funds. It is recommended that the board of trustees should amend the rules governing the GEPF in order to remove this debt system, because it unnecessarily prejudices its members.

\section{Bibliography}

\section{Literature}

Bell 2006 Business Law \& Tax Review

Bell "Credit Act may affect retirement funds" 2006 (Nov) Business Law \& Tax Review 9

Khoza "History of retirement funds"

Khoza F "History of retirement funds, their purpose and the framework of retirement funding in South Africa" Unpublished contribution delivered at the Pensions Seminar hosted by the Black Lawyers Association and The Pension Lawyers Association (6-8 March 2005)

Manamela 2007 SA Merc LJ

Manamela $T$ "Deductions from Pension Benefits for Purposes of Section 37D of the Pension Funds Act 24 of 1956: Employers forced to tow the line" 200719 SA Merc LJ 189-203 189

Marumoagae 2013 De Rebus 38-41

Marumoagae $C$ "Breaking up is hard to do, or is it? The Clean Break Principle Explained" 2013 (Oct) De Rebus 38-41 
Marumoagae 2014 Speculum Juris 54-73

Marumoagae C "A Critical Discussion of a Pension Interest as an Asset in the Joint Estate of Parties Married in Community of Property" 20141 Speculum Juris $54-73$

Marumoagae 2014 PER 2488-2524

Marumoagae $C$ "Non-member's Entitlement to the Pension Interest of the Member's Pension Fund" 20146 PER 2488-2524

Mhango 2014 Speculum Juris

Mhango M "Adjudicating insurance and Pension products under the South African Pension Funds Act 24 of 1956" 20142 Speculum Juris 101- 122

Nevondwe 2012 Insurance and Tax

Nevondwe L "Government Employees Pension Fund: Payment to Member Spouse on Divorce" 2012 Insurance and Tax 32-35

Nevondwe 2014 "Divorce orders: issues for pension funds"

Nevondwe 2014 "Divorce orders: issues for pension funds" Unpublished contribution delivered at Pension Lawyers Association Conference (02 March 2014 Cape Town)

Olivier and Van Rensburg 2000 LDD

Olivier \& Van Rensburg "Protection and enforcement of the right to social security" 20001 LDD 87-99.

\section{Register of Statutes}

Constitution of the Republic of South Africa, 1996

Divorce Act 70 of 1979

Financial Services Laws General Amendment Act 22 of 2008

Government Employees Pension Fund Law Amendment Act 19 of 2011

Government Employees Pension Law of 1996

National Credit Act 34 of 2005

Pension Funds Act 24 of 1956

Pension Funds Amendment Act 11 of 2007

Post Office Act 44 of 1958 
Transnet Pension Fund Act 62 of 1990

\section{Register of case law}

Cockcroft v Mine Employees' Pension Fund 20073 BPLR 296 (PFA)

Harksen v Lane 199711 BCLR 1489 (CC)

Mouton v Southern Staff Pension Fund 20034 BPLR 4581 (PFA)

Ngewu v Post Office Retirement Fund 2013 (4) BCLR 421 (CC)

Prinsloo v Van der Linde 19973 SA 1012 (CC)

Standard Bank of South African Ltd $v$ Kelly (unreported) case number $23427 / 2010$ of 25 January 2011

Wiese v Government Employees Pension Fund 20126 BCLR 599 (CC)

Van der Merwe v Road Accident Fund 20064 SA 230 (CC)

\section{Internet Sources}

GEPF 2014 http://www.gepf.gov.za/index.php/about_us/article/who-is-gepf GEPF http://www.gepf.gov.za/index.php/about_us/article/who-is-gepf accessed 10 October 2015

GEPF 2014 http://www.gepf.gov.za/index.php/news/article/gepf-investsr312-million-in-a-solar-park-project

GEPF 2014 "Clean-break principle brings GEPF in line with the Pension Funds Act" http://www.gepf.gov.za/index.php/news/article/gepf-investsr312-million-in-a-solar-park-project accessed 20 October 2015

National Treasury $2012 \quad$ http://www.treasury.gov.za/comm media/press/2012/Incentivising\%20non-retirement\%20savings.pdf National Treasury Incentivising non-retirement savings Discussion paper (2012)

3http://www.treasury.gov.za/comm_media/press/2012/Incentivising\%20no n-retirement\%20savings.pdf accessed 10 October 2015

SALC Discussion paper 1998 http://www.justice.gov.za/salrc/dpapers/ dp77_prj112_1998.pdf 
South African Law Commission Discussion Paper 77: Project 112 Sharing of Pension Benefits (1998) http://www.justice.gov.za/ salrc/dpapers/dp77_prj112_1998.pdf (5 accessed 25 Oct 